\title{
deslocamentos crianceiros, conversas transviadas: coisas da educação e de afirmação de uma vida que importa ${ }^{1}$
}

\author{
alexsandro rodrigues ${ }^{2}$ \\ universidade federal do espírito santo - ufes, brasil \\ castiel vitorino brasileiro ${ }^{3}$ \\ universidade federal do espírito santo - ufes, brasil \\ jésio zamboni ${ }^{4}$ \\ universidade federal do espírito santo - ufes, brasil \\ marcelo santana ferreira ${ }^{5}$ \\ universidade federal do espírito santo - ufes, brasil \\ steferson zanoni roseiro 6 \\ universidade federal do espírito santo - ufes, brasil
}

resumo

A partir da premissa que a criança é um outro perigoso que precisa ser controlado, esse artigo propõe acompanhar - e, em dada medida, inventar - as infâncias errantes, desviadas e transviadas como campo de possibilidades para afirmar uma vida que difere de si mesma. Compreendendo a partir de René Schérer, Guy Hocquenghem e Michel Foucault que as infâncias são relegadas a uma ordem de instituições que as sequestram sem parar, isto é, que veementemente se lançam sobre elas para lhes ceifar o campo das possibilidades, esse texto tenta se aliar às crianças e as suas travessuras. Assim, essa escrita busca afirmar a criança enquanto categoria analítica, enquanto ficção de processos de rememoração. Nessa aventura, é o processo de invenção que se alia à memória e põe para trabalhar os conceitos e as afecções da racialidade, de gênero e de sexualidade. Aqui, é a criança que borra os limites dessas categorias, que faz sumir as estabilidades da existência. Porque malditas, as crianças (des)viadas não se satisfazem com as infâncias sequestradas que lhes imprimem. Riem e zombam das histórias da infância tão confortavelmente contadas no mundo dos adultos. As crianças aqui presentes são potentes justamente por estabelecerem linhas de resistência frente às violências, ao racismo, à heterossexualidade compulsória, à misoginia. Travessas, as crianças apenas riem e convidam aos outros com seus rastros de traquinagem.

palavras-chave: criança; infância; identidade; sexualidade; raça.

\footnotetext{
${ }^{1}$ Esse artigo é resultado de uma pesquisa de pós-doutorados e de iniciação científica com a qual os autores estão envolvidos desde 2016.

2 E-mail: xela_alex@bol.com.br

3 E-mail: castielvitorinob@gmail.com

4 E-mail: jesiozamboni@gmail.com

${ }^{5}$ E-mail: celos.ferreira@gmail.com

6 E-mail: dinno_sauro@hotmail.com
} 
deslocamentos crianceiros, conversas transviadas: coisas da educação e de afirmação de uma vida que importa

\section{displacements, misplaced conversations: things of education and affirmation of a life that matters}

abstract

From the premise that the child is a dangerous other and that so must be controlled, this essay proposes to accompany - and, someway, to invent - the errant, devious and fag childhood as a possibility field to affirm the life that differs from itself. Understanding with René Schérer, Guy Hocquenghem and Michel Foucault that the childhoods are relegated to an order of institutions that kidnaps them in nonstop, it is, an order of institutions that strongly haunt the childhoods to reap the possibility fields, this text tries to ally with the children and their tricks. Therefore, this writing aims to affirm the child as an analytical category, as a fiction of the remembrance processes. In this adventure, it is the invention processes itself that allies to the memory and makes the concepts and the affects of raciality, gender and sexuality work. Here the child erase the limits of those categories and throw in the air the stability of the existence. Because they are tricky, the errant children do not satisfy themselves with the kidnaped childhood on selling. They laugh and mock on the comfortable childhood stories told in the adult world. The children here presented are powerful because they stablish resistance lines to face the violence, the racism, the compulsory heterosexuality and the misogyny. Tricky, the children just laugh and invite the others with their trail of romp.

keywords: child; childhood; identity; sexuality; race.

\section{desplazamientos niñeros, conversaciones transviadas: cosas de la educación y de afirmación de una vida que importa}

resumen

Partiendo de la premisa de que el niño es un otro peligroso y que debe ser controlado, este ensayo propone acompañar - y, de alguna manera, inventar - la infancia andante, desviada y maricona como un campo de posibilidad para afirmar la vida que difiere de sí misma. Comprendiendo con René Schérer, Guy Hocquenghem y Michel Foucault que las infancias están relegadas a un orden de instituciones que las secuestran sin parar, esto és, un orden de instituciones que persiguen fuertemente a la infancia para cosechar los campos de posibilidades, este texto trata de aliarse con los niños y sus trucos. Por lo tanto, este escrito apunta a afirmar al niño como una categoría analítica, como una ficción de los procesos de recuerdo. En esta aventura, es el proceso de invención el que se alía con la memoria y hace que los conceptos y los efectos de la raza, el género y la sexualidad funcionen. Aquí el niño borra los límites de esas categorías y lanza al aire la estabilidad de la existencia. Debido a que son engañosas, los niños andantes no se satisfacen con la infancia secuestrada al vender. Se ríen y se burlan de las cómodas historias infantiles contadas en el mundo de los adultos. Los niños aquí presentados son poderosos porque establecen líneas de resistencia para enfrentar la violencia, el racismo, la heterosexualidad obligatoria y la misoginia. Traviesos, los niños solo se ríen e invitan a los demás con su rastro de jugueteo.

palabras clave: niño; infancia; identidad; sexualidad; raza. 
deslocamentos crianceiros, conversas transviadas: coisas da educação e de afirmação de uma vida que importa ${ }^{7}$

\section{alerta de contaminação}

Os inomináveis são os que não são nem isto nem aquilo. Aquilo que não se presta ao jogo da oposição nem de sua lógica. Aquilo que deixa a ordem sem efeito, que desordena. Os inomináveis fragilizam todo conhecimento, toda determinação. São, por isso mesmo, a indeterminação, o adiamento do conhecimento, o deixar para depois e sempre para depois - toda classificação, toda definição, toda catalogação. E ao chegar esse depois, deixar outra vez de lado a certeza de todo nome para continuar órfão do maleficio da ordem. (SKLIAR, 2003, p. 55)

Se a criança importa, por que, irremediavelmente, esperamos que ela "entenda" as coisas quando crescer, quando for "adulta"? Se a criança importa, por que o conceito de maturidade funciona tão asperamente para aquele que evoca uma criancice quando não mais se é considerado criança? Se a criança importa, porque temos tanto medo de nos aventurarmos nas heterotopias das crianças que nos habitam em movimentos ariscos e desordeiros?

As heterotopias são produzidas historicamente como "espaços absolutamente outros", espaços fora do todo, não totalizáveis, pois múltiplos: "Em geral, a heterotopia tem como regra justapor em um lugar real vários espaços que, normalmente, seriam ou deveriam ser incompatíveis" (FOUCAULT, 2013, p. 24). Foucault cita, por exemplo, os asilos, as prisões e as escolas. Todavia, há também forças nas heterotopias que produzem pausas temporais e rupturas de funcionamento, ocasionando a produção de novos espaços pelos tensionamentos entre lugares sobrepostos. A infância funciona entre os espaços da vida coletiva, especialmente entre a família e a escola (SCHÉRER, 1982; 1983), mas também entremeando a mídia, o hospital, o judiciário... compondo um limbo a erodir os

\footnotetext{
${ }^{7}$ Esse artigo é resultado de uma pesquisa de pós-doutorados e de iniciação científica com a qual os autores estão envolvidos desde 2016.
} 
deslocamentos crianceiros, conversas transviadas: coisas da educação e de afirmação de uma vida que importa

limites entre os espaços, produzindo espaços outros, heterotopias. Essas zonas de hibridismo, entre lugares, nos provocam a pensar uma infância impensável.

A heterotopia é o avesso da utopia, do não-lugar. Utópico é o projeto civilizatório da modernidade ocidental, obcecado por projetos educativos destinados à falência e continuamente submetidos a reformas (SCHÉRER, 2007). Tal destinação da educação atém-se à moderna concepção de infância, produzindo a criança como ser incompleto, necessitado de constantes vigilância e controle, desejada como morta, já que seu sentido é apenas o deixar de ser criança para tornar-se adulto (SCHÉRER, 1982; 1983). As heteropias da infância são pontos de corte nesse projeto predominante, desvios que possibilitam a produção de outras infâncias, agenciamentos de desejo infantil rompendo os limites do dispositivo infantilizador.

A reversão da infância, como a reversão do platonismo (DELEUZE, 2007), não consiste simplesmente em abolir a ideia, no caso a de criança, nem a distinção entre mundo sensível infantil e mundo inteligível adulto. Trata-se de uma tarefa mais difícil, a de encurralar, como o fizeram Schérer (1982; 1983; 2016) e Foucault (2014), o pedagogo, os pais e os psis, descobrindo-lhes as motivações para a invenção moderna da infância. Essa primeira tarefa negativa, crítica, porém não encerra o problema; ela o abre para uma segunda e crucial tarefa, a da reversão propriamente, consistindo em desvelar na infância "uma outra faceta", que "por sua natureza, ela reúne em si o começo e o fim; ela desborda o tempo histórico no que diz respeito à meta a atingir e ao ideal" (SCHÉRER, 2009, p. 20-22). Por essa via, pode-se encontrar outras composições da infância a partir do rapto, que instaura outras relações entre infância e adultez (SCHÉRER; HOCQUENGHEM, 2016).

Buscamos acompanhar as infâncias errantes, desviadas e transviadas como campo de possibilidades para afirmar uma vida que difere em si própria de si mesma. A criança deixa assim de ser o outro, aquilo que já não podemos ser mais, para tornar-se outramento do mundo, modificação das paisagens de um destino. Nossas vidas, no rastreio dessas infâncias outras, aparecem como relâmpagos em 
nossas memórias e são evocadas de modo a podermos nos aventurar em experimentações singulares com o corpo, o gênero, a sexualidade e a raça nos pontos em que se cruzam. As crianças ariscas que nos interessam não são necessariamente nós mesmos, pois nos modificamos nesse exercício criançante. Trata-se de crianças narradas num rompante de práticas de si, a rejeitar qualquer ordem. As crianças ariscas que nos interessam não buscam a seguridade familiar, a organização escolar ou o aconselhamento psi. A ordenação do mundo não dá conta dessas crianças. Encontra-se nelas uma desordem que o modo adulto não conseguiu capturar, restando como segredo.

Daí que, mesmo aqui, enquanto escrevemos, não damos conta delas, não as resolvemos, nem queremos isso. Essas crianças, malditas, não podem ser encontradas nos manuais de bom comportamento da puericultura, da boa pedagogia e da psicologia do desenvolvimento. Por transbordarem em si, não cabem nesses lugares e, decerto, nem aqui - ainda que tentássemos! Nesses lugares, que buscam fixar um ideal para pensar e desejar a criança moderna, não serão encontradas. Não fazem questão! Debocham de tais tentativas! Nós também debochamos dos bons manuais. Errôneos e errantes que sejamos, também de nós as ariscas crianças riem, ou melhor, conosco. A maior seriedade encontra-se nesse riso escarnecedor das boas intenções. Nossa aliança com elas acontece por meio dessa alegria. Vez ou outra, achamos que elas nos dão um empurrãozinho, um sorriso ou um beliscão e, com isso, empolgamonos tanto que acabamos por pensar sermos diferentes. Vez ou outra, essas crianças aparecem em ensaios dalguns corpos enlouquecidos e tornam-se razões de infâmia e de má fé. Ah, por onde passam, essas crianças contaminam as lógicas que as cerceiam!

Borrando qualquer corpo "original", supostamente inocente e angelical, elas desaparecem onde os olhos as querem e aparecem onde nosso tato as sente. Antes da linguagem, o corpo da criança se produz pelo toque (SCHÉRER; HOCQUENGHEM, 2016), por isso a norma moderna da infância visa sobretudo o "não tocar" (SCHÉRER, 
deslocamentos crianceiros, conversas transviadas: coisas da educação e de afirmação de uma vida que importa

1982), a fim de esvaziar a criança de sua potência e defini-la como falta de maturidade. Mas elas insistem em contaminar, por superfície porosa de sedução, qualquer olhar, qualquer afago; fragilizam as mocidades, interrompem as adultices, fazem maliciosas pompas com a mesmidade. Riem do adulto, dos frágeis projetos adultocêntricos que a tudo buscam colonizar! E, com a força da criança como novidade, em sua potente outridade, esses projetos feitos histórias higienizadas, (re)escritas nos acordos da moral colonizadora, podem ser abalados e fraturados com a simples e sedutora presença de um outro que, em sua sedução e rapidez, ameaça a tranquilidade do bom sono e sonho do mundo adulto. É esse outro, sempre em vias de diferir, que assombra a mesmidade a reagir violentamente contra as criancices.

- Não passe por aquele caminho! Ali mora uma bruxa que faz sopa de criança teimosa!

- Não ande com aquele menino, ele não é uma boa companhia para você!

- Nunca aceite balas e doces de estranhos! Eles podem sequestrar você.

- Não sente no colo de estranhos e não deixe que nenhum estranho coloque a mão sobre seu corpo. Seu corpo é sagrado. Somente a mamãe e a papai podem lhe tocar!

- Não tranque a porta do quarto e do banheiro!

- Menino, o que faz tão quietinho aí! Aposto que está aprontando...

- Vou cortar as suas asinhas! Você está muito atrevidinho!

- Nada fica escondido sob o olhar de Deus. Pode até achar que está me enganando, mas Deus está vendo e ele irá castigar você!

- Nem pense em fugir de casa!

$\mathrm{Na}$ criança capturada por tais discursos, descorporificada, investem-se formas de eliminação, com promessas corretivas, seduções trapaceiras que almejam desmontar na criança atrevida, desviada e transviada os jogos de vagabundagem. Sobre a criança endiabrada investem-se as mais difusas instituições de sequestro e as mais terríveis chantagens afetivas. Cansadas de pensar nesses jogos perigosos da sedução dos poderes, interessa-nos, aqui, pôr em funcionamento as caricaturas de nós mesmas, as máscaras desengonçadas de pinóquios, as infâncias inomináveis, as que não são anjos e nem querem ser, as que escapam e que produzem linhas de escape por dentro das instituições de sequestros, fazendo escândalos às chantagens afetivas. 
Na menor das intenções, interessa-nos unicamente contar outras histórias sobre nós mesmas.

É assim que essa escrita segue: olhamos para as seduções (a)diante os sequestros tão estrategicamente elaborados, tão avidamente anuladores, que recaem sobre nossas infâncias e os corpos-crianças infinitos. Todavia, ao fazermos isso, fazemos apenas como jeito de evocar memórias das crianças desviadas, transviadas, enérgicas, embebidas na astúcia da vida vadia. Na trilha de René Schérer e Guy Hocquenghem (2016), pintamos, talvez, memórias de crianças que nunca existiram ou, melhor, de crianças que querem fazer não existir. Nós, beliscadas em suas travessuras, damos logo o alerta de contaminação.

\section{rimos na cara do perigo}

Uma van para na frente de uma escola, uma menina - apenas uma criança mais velha - chama outras duas crianças, bem menores, e leva-as para a escola. As três crianças são muito bem recebidas, dão-lhes "bom dia", abraços, conversam e o dia segue como outro qualquer. Um menino é levado, pelo avô, a uma escolinha de balé - primor da revolução, dizem - e fica contente em deixar a criança lá, abraçandoa na despedida. Em suma, os sequestros são infinitos, configurando heterotopias de captura.

Por instituições de sequestro, compreendemos todas as instituições que, de uma certa forma, se juntam em planos e estratégias comuns e põem em movimento o desejo pela ordem, na tentativa de garantir o trilhar adulto da criança via técnicas ortopédicas (SCHÉRER; HOCQUENGHEM, 2016). E, decerto, investimento é o que não lhes falta! Os mais infinitos espaços são criados para capturarem as malandragens das crianças, e, ao mesmo tempo, os mais maravilhosos espaços fora do espaço. Criam-se, em shoppings e outros lugares da cidade, cada vez mais espaços de criança que, em absoluto, carregam elementos de todos os mundos, de todos os tempos: videogames, escorregadores, livros, músicas, fantasias, espelho, brinquedos, 
deslocamentos crianceiros, conversas transviadas: coisas da educação e de afirmação de uma vida que importa

mas também colchonetes e travesseiros. O sequestro só é possível pela sedução. E a criança é quem precisa ser seduzida porque ela, antes mesmo de se situar em qualquer espaço, interrompe-o, rasga-o e foge, fazendo vazar.

E os adultos, tão ordenados, morrem de medo de qualquer bagunça. Basta que lhes sumam com as vassouras e outros aparatos de limpeza e organicidade que logo surtam; basta que as empregadas mandem uma mensagem dizendo que está doente que os ataques de pânico se iniciam. Daí o aparato da heterotopia tão pertinente na captura de corpos. Daí, também, que tantas heterotopias sejam evocadas para captar os corpos que fogem ou deliriam os espaços.

Curioso, entretanto, é que as capturas das crianças só são possíveis porque, a todo o momento, os saberes hegemônicos insistem em afirmar a criança como substantivo. Insistem em contar histórias de uma criança que não passa de um corpo germinal, de uma criança que não passa de um objeto quase sem vontade, quase sem existência. Os adultos contam a história das crianças apenas a partir do momento em que elas são sequestradas e esse é, talvez, o problema das histórias das infâncias, sejam elas quais forem.

Todavia, antes de qualquer sequestro, antes da vida da criança passar a ter valor (monetário, identitário... nos códigos da branquitude, da sexualidade, da cisgeneridade), as crianças já eram fabuladas e já fabulavam, já inventavam corpos, movimentos, danças, lugares. O sequestro prevê um fim, um momento em que a transação final é feita depois de um longo jogo de negociação. "Quer uma prova?", perguntam os sequestradores aos familiares, mostrando, a cada vez, uma nova imagem da infância; e, provada a vida do corpo, voltam a guardá-lo zelosamente para que os valores possam continuar sobre a mesa. Por fim, dizem: "Pague-me com sua infância e dar-lhe-ei liberdade". Nesse momento, já estão com todas as moedas em mãos e, ainda assim, almejam tirar da própria criança aquilo que ela já não mais é, quando traçam infâncias evolutivas. Como Skliar (2014, p. 140) lembra, "tudo o que é evolutivo conduz à morte". 
Arteiras que só, as crianças parecem quase involuir, quase retroceder no tempo, no espaço, nas organizações. Não que elas retrocedam exatamente. Não é isso que lhes interessa, a bem da verdade. Mas, a cada lógica de maturidade estabelecida, a criança viada preta maldiva ${ }^{8}$ faz os mais inversos e desconexos movimentos. Como no funk da Mc Xuxú e a Mc Trans, as loucuras crianceiras fazem seus escândalos em um crescimento que em nada tem a ver com o passar dos anos, mas com o aumento do incômodo capaz de causar. "Sempre ouvi dizer que eu sou muito atrevida / Eu cresci, me transformei, virei maldiva".

Maldivas, essas crianças-infâncias ${ }^{9}$ ariscas que não podem ser sequestradas por não possuírem rostos e por não crescerem em igual sentido, funcionam aqui como contradispositivo de saberes e desejos normativos. Reafirmamos com Larrosa (2004, p. 184) que uma suposta versão de infância “é algo que nossos saberes, nossas práticas e nossas instituições de sequestros já capturaram: algo que podemos explicar e nomear, algo sobre o qual podemos intervir, algo que podemos acolher". Infâncias coexistem umas com as outras. Nosso interesse é com o acolhimento da diferença, as inomináveis, as que assustam e zombam. A bem da verdade, as heterotopias sociais que Foucault chama de heterotopias do desvio - aquelas "reservadas aos indivíduos cujo comportamento é desviante" (FOUCAULT, 2013, p. 22) - em nada nos interessa. Interessam-nos as heterotopias crianceiras, lugar das utopias do corpo descabelado, do corpo desengonçado, desviado, desavisado, transviado. Junto a essas infâncias, no momento que nos encontramos com suas fugas, só nos cabe, como tarefa, acolhê-las nos que elas trazem nos seus rastros, nos seus indícios de aparição. De posse do apresentado por Jorge Larrosa, no fazemos perguntas: Que infâncias foram capturadas? Que infâncias foram nomeadas? E as crianças que não ousamos sobre ela falar? Por que temos tanto medo da criança, principalmente da criança marcada por

\footnotetext{
8. O termo maldiva, contração da maldita com a diva, remete ao uso que a Mc Xuxú e a Mc Trans fazem na música homônima que viralizou com o clipe publicado no canal da Mc Xuxú em 10 de julho de 2016.

9 Assumiremos a escrita criança-infância hifenizada como forma de ampliarmos as possibilidades interpretativas e sua potência de deslocamento.
} 
deslocamentos crianceiros, conversas transviadas: coisas da educação e de afirmação de uma vida que importa

insterseccionalidades como raça, gênero, identidade de gênero e dissidências sexuais? E quando falamos de criança e de infância, estamos dizendo e também fabricando a mesma coisa?

Apesar do risco, esperamos seriamente que não!

Interessam-nos as crianças que vivem suas heteropias com seu corpo incorporal, onde não se apaga a força do corpo, apenas o potencializa. Esse lugar existe e Foucault vai nos dizer que podemos encontrá-lo ao nos permitir nos perder nas utopias do corpo. Nos seus dizeres, "tudo o que concerne ao corpo - desenho, cor, coroa, tiara, vestimenta, uniforme - tudo isso faz desabrochar, de forma sensível e matizada, as utopias seladas no corpo" (FOUCUALT, 2013, p. 13). Daí que, como ele destaca,

A utopia é um lugar fora de todos os lugares, mas um lugar que eu teria um corpo sem corpo, um corpo que seria belo, límpido, transparente, luminoso, veloz, colossal na sua potência, infinito em sua duração, solto, invisível, protegido, sempre transfigurado; pode bem ser que a utopia primeira, a mais inextirpável no coração dos homens, consista precisamente na utopia de um corpo incorporal. $\mathrm{O}$ pais das fadas, os país dos duendes, dos gênios, dos mágicos, este é o país onde os corpos se transportam tão rápido quanto a luz, o país onde as feridas se curam com um balsamo maravilhoso na duração de um relâmpago, o país onde se pode cair de uma montanha e reerguerse vivo, o país onde se é visível quando se quiser, invisível quando se desejar. Se existir uma país feérico, é justamente para que eu seja príncipe encantado e que todas as janotas graciosas tornem-se peludos e vilões como pequenos ursos.

Bem sabemos do risco do corpo utópico, do risco da utopia do corpo incorpóreo, ou, como Denise Najmanovich (2001) falava, sabemos do risco do corpo desencarnado. Todavia, ainda que a maior utopia talvez seja a do corpo-sem-corpo, junto a esse risco, coexiste o risco do amar. "Sob os dedos do outro que nos percorrem, todas as partes invisíveis [e incorpóreas] de nosso corpo põem-se a existir" (FOUCAULT, 2013, p. 16). Sob o risco do corpo inexistente, dança o risco da utopia do amor e, sem preâmbulos, Foucault logo afirma: "no amor o corpo está aqui". 
Assim é que, pensando a criança-infância não capturada, compreendemos que não podemos desvincular o debate do corpo marcado dessa criança com as marcas de sua existência que existe no contato-contágio com o outro. O corpo, aos modos de Foucault, é um lugar utópico. Pelo corpo se tatuam e hibridizam histórias as mais diversas, afetos os mais caros e, com isso, leituras e interpretações também acontecem. Compreendemos que o corpo como heterotopia - isto é, corpo como lugar das utopias - está passível de diversas escrituras e leituras, que se diferenciam de acordo com a cultura na qual ele se encontra. Se é possível leituras, com o corpo e nele viver os híbridos, no entre lugar e fora do lugar é porque outros agenciamentos acontecem. E com que tintas escrevemos as histórias que marcam o corpo da criança que não afirma em seu existir as marcas do (hetero)(cis)tema e faz abalar e ou ruir os muros da raça, do gênero e da sexualidade?

Breve resposta: com pinceladas de carícias, de histórias que só podem ser contadas entre crianças porque, como um corpo rememora, há coisas que não podem ser contadas entre adultos, porque, sem ofensas a nós mesmos, quem não entende somos nós, os adultos.

Toda vez que eu ia ao banheiro, meu primo ia comigo e toda vez que ele ia, eu ia com ele. A gente vivia indo juntos. E, quando um não percebia, o outro falava "Me vigia?" ou "Eu te vigio"... Hahahaha. As pessoas achavam aquilo engraçado... viviam brincando: "Tá com medo de cair no vaso, é?". Pobres adultos! A gente gostava mesmo era de ver o outro pelado, de segurar a mão um do outro e, de vez em quando, de uns beijinhos. Nossas diferenças de pele ficavam ótimas na proximidade. Mas ninguém desconfiava de duas crianças de seis ou sete anos. Onde já se viu, né? Se alguém comentava a estranheza, logo falavam que as ideias eram minhocas na cabeça dos outros. Nós, criancinhas, nem entendiamos o que era isso. Hahaha.

Meu pai era preto, minha mãe era branca, mas não tinha piru, então, até onde me lembro, a primeira vez que eu vi um piru branco, achei fascinante. Eu tava acostumado com o meu tom de chocolate ao leite, hahahaha, e com o do meu pai... eu era novinho, acho que tinha uns cinco anos! Aí eu reparei naquela coisa branca pendurada do meu primo. Enem era grande! Ele era da minha idade, então era tudo normal! Mas achei tão diferente que eu peguei na 
deslocamentos crianceiros, conversas transviadas: coisas da educação e de afirmação de uma vida que importa

hora! E, detalhe, foi a primeira vez que brincamos de luta de espadinhas. Adoro! (Relatos de Memória-Criança) ${ }^{10}$.

E, sendo nossos corpos marcados por relações de poder, onde raça, sexualidade, questões econômicas e territoriais se inscrevem aos modos de um palimpsesto, fazemos volteios na temática, acreditando ser possível contemplar as crianças invisíveis e ou invisibilizadas pelas teorias e discursos que se tornaram hegemônicos nos espaços educativos e que se esforçam cotidianamente para fabricar a criança universal do sonho dos adultos. A bichinha preta - chocolat au lait - rouba, para si, o corpo do outro e, na brincadeira com espadas, fazem dois corpos existirem. Não há necessidade de se dizer o lugar do encontro, desses jogos de pele, a bem da verdade, o lugar poderia ser qualquer um: sendo crianças, jamais poderiam experimentar a pele com a pele, e, assim, qualquer contato-contágio faz ruir os espaços, as sombras da Criança Real dos bons manuais.

Outras infâncias, outras crianças, outros corpos, outros jogos de raça e identidades fazem tremer a vida de todo dia quando dispostos estamos a nos colocarmos na trama da conversa atrevida para falar, escrever, memorar o que consideramos ser territórios contestados. Elas existem. Não a vemos, pela simples razão de não as compreender e/ou, porque muitas vezes delas não queremos falar e ou rememorar. E, outras tantas, por simplesmente não lhe darmos razão, afinal, quem acredita piamente na criança, não? Mais ainda, se ela for preta e viada! Um corpocriança fala:

Lembro que um amigo meu do condomínio vivia pedindo para ver meu cuzinho. Ele não fazia nada, só pedia para eu abaixar as calças e mostrar o cu para ele. Ele ficava olhando e eu ficava lá, inclinado, para ele olhar melhor. Nunca entendi e acho que continuo sem entender! Talvez fosse porque o dele fosse rosinha e o meu fosse arroxeado, fosse escuro, vai saber. Só sei que, pelo menos uma vez por semana, lá estava ele lá em casa... a gente começava a brincar e ele pedia sem pudores: "Deixa eu ver sua bundinha?" (Relatos de Memória-Criança).

10 Nesse texto, todos os relatos são designados como "Relatos de Memória-Criança", ainda que, em absoluto, não sejam todos de uma mesma pessoa. Optamos por manter inomináveis todas as narrativas não por uma questão de segurança, mas de aposta política na qual o corpo opera em um sem-rosto incapturável. 
Falemos, pois, dessas crianças-infâncias funcionando como contradispositivos de um frágil projeto de modernidade e humanidade. Falemos, pois, dessas crianças que se divertem com seus corpos sabendo, antes de tudo, que eles existem e que são muito mais interessantes diante dos olhos do outro, diante da pele do outro.

\section{paixões negras desviadas}

Aos 12, comecei a encarar a minha "orientação sexual". Não sei porque orientação se eu não fui orientado! Reconheci que eu fora uma criança suja, imunda, perversa, pervertida. Sempre gostei do sexo sujo e pervertido. Safado. Ao ponto de falar putarias no ouvido. Desinibido. O suor que escorre do corpo excita. O pegar. Mas nunca aceitei. Não tive coragem. Vamos voltar naquela parte em que era tímido e quieto. Guardei. Guardei só para mim. Fui caçoado. Mas não ligara para tal. Foram experiências estranhas. Ao mesmo tempo prazerosas, excitantes e aventureiras. Foram complexas. Pesadas. Incríveis. Queria sempre ir além. Conhecimento é necessário. Eu precisava.

É por esse convite à pele que, talvez, devêssemos abrir a indagação sobre quem, exatamente, é a criança desejante. Virginie Despentes (2016) fala de um corpo mais desejante que desejado e, talvez para a criança preta, viada e pobre essa lógica seja estranhamente cabível. A criança branca, engomada, certamente é desejada em demasia. A ela não é necessário pele alva, não se enganem! Muitas crianças são brancas no europismo das (pretensas) raízes racionais e no americanismo dos consumos! Ao mesmo tempo, dizem que criança nenhuma é desejante, afinal, ela nem saberia o que é isso! Curiosamente, se a criança for já desviada (preta, bicha, gorda, feia, vagabunda, de rua, pobre, macumbeira, louca, etc.)... "Bem, nesse caso...", dizem os bem sabidos.

Nesse caso, as histórias são outras. No caso dessas crianças desviadas, o corpo é sempre mais seduzente, mais desejante. A criança preta torna-se viada ao coletivizar-se. Produz, por uma via inesperada, heterotopias, lugares inauditos em que se gestam modos de viver, compartilhando-os. Ao se agrupar, estabelece contato com outros corpos que intensificam, expandem as possibilidades de um corpo criança. Mas não se trata de desenvolvimento, mas de envolvimento com um outro da criança, um estranho, um monstro abominável junto com a pureza angelical da 
deslocamentos crianceiros, conversas transviadas: coisas da educação e de afirmação de uma vida que importa

infância. Há uma "contaminação de viadagem", uma contaminação da própria infidelidade das infâncias. Sendo assim, compreende-se que o que ocorre são trocas absurdas, experimentações divertidas, identificações precárias e transferências circulantes de maneiras singulares de corporificar e expressar aquilo que poderíamos nomear como negritude viada.

Aos modos da cultura pop, talvez pudéssemos dizer, com uma música da Aretuza Lovi, que a criança-infância - sempre mais desejante! - contamina os corpos à sua volta, faz nascer em cada corpo uma carne delirante, uma carne vagabunda. Essas crianças, que fomos e que nos carregam, parecem cantar sem parar o refrão da música: "Quando eu mexer a minha bunda / vagabundo pira até segunda".

O corpo da criança preta viada vadia, de alguma maneira, evoca a figura do vagabundo, como quem age contra o sequestro, que age contra a instituição da masculinidade do negro másculo, do negro viril. Demorando-nos um pouco mais dessa força que a música e o termo vagabundo operam, talvez seja possível dizer que o vagabundo é aquele corpo que, por obsolescência, isto é, por falta de uso real, rouba todo o futuro da criança.

E, não sejamos ingênuos, as crianças adoram produzir esse vagabundo inquietante porque elas mesmas não são outra coisa!

Ao longo da infância, fui criando uma rede de amigos e colegas. Brincávamos sempre juntos, e gostávamos de explorar os quintais dos nossos vizinhos, que eram repletos de árvores enormes. Lugares perfeitos para lermos as revistas pornôs que achávamos em nossas casas, e nos tocarmos sem sermos descobertos. Lembro-me de duas vezes em que a exploração também se deu sobre nossos corpos. Foi uma espécie de bacanal, onde todos se experimentavam da maneira que achasse melhor. Sem pudor e sem culpa. Havia também os encontros para apenas ficarmos lendo as revistas pornográficas, onde, se minha memória não falha, também ocorriam alguns momentos de masturbação coletiva (Relatos de Memória-Criança).

E, decerto, a criança-mão-coletiva fricciona a ordem ao limite de sua paciência.

Ora, é justamente pela criança ficcionar e friccionar o outro, o novo e, o caos, que existem e se inventam diversas práticas de disciplinarização e domesticação para pensar esse sujeito. Foucault, incisivamente em Vigiar Punir (2002) sobre isso, muito 
bem nos ensinou. Contudo, essas práticas se diferenciaram entre as próprias crianças, para crianças diferentes, ações diferentes. A polícia da infância muito bem sabe disso! Estamos todos nós envolvidos com sua fabricação. A infância fala de uma vida e a vida de um corpo. Todos os corpos possuem vida, mas nem todas as formas de vidas são consideradas vivas, passíveis de luto (BUTLER, 2015). Uma vida LGBT11 é precária, vista e tida como um projeto que deu errado. Contudo, existem crianças que não vivenciam essa precariedade, por não apresentarem nenhum comportamento que vá ao encontro dessas dissidências. Entretanto, isso não ocorre com crianças negras, que, independente das dissidências sexuais, seus corpos desde sempre estão marcados pelos sentidos de precariedade e inferioridade a eles acoplados por nossas histórias de racistas. Elas se fabricam nas ruas, vielas e becos.

O cotidiano de uma criança que possui uma sexualidade considerada desviante da heteronorma carece de investigação, problematização, principalmente, quando interessadas estamos em tencionar as intersecções com raça e classe. Não é preciso muitos esforços para falar de rascismos e LGBTfobias. Como Judith Buttler (2015, p. 17) não nos deixa esquecer, "há sujeitos que não são exatamente reconhecíveis como sujeitos e há vidas que dificilmente - ou, melhor dizendo, nunca - são reconhecidas como vidas", e, ao mesmo tempo, indaga em que "sentido, então, a vida excede sempre as condições normativas de sua condição de ser reconhecida?".

As maneiras pelas quais a negritude é negada são tão múltiplas quanto às formas pelas quais ela se manifesta - através da estética, da dança, das artes e da literatura (acadêmica ou não), por exemplo. Não basta nascer negro, é preciso tornase negro. Armamo-nos politicamente em e com um corpo negro, em e com um corpo viado-preto que não se fia sozinho, não se encontra com o vazio. Querem nos sequestrar as infâncias, disso não temos dúvidas, todavia, as crianças-pretas-viadas, parte das crianças-infâncias, fogem por entre ruelas, no escuro dos quartos que brincam de gato-mia ou de pique-esconde.

${ }^{11}$ LGBT é a sigla referente às identidades Lésbicas, Gays, Bissexuais, Travestis e Transgêneros 
deslocamentos crianceiros, conversas transviadas: coisas da educação e de afirmação de uma vida que importa

Já brinquei muito de gato-mia só para miar baixinho quando algum amigo bonitinho colocava a mão em mim... e eu sempre fazia questão de deixar acessivel apenas as partes do meu corpo que eu queria que encostassem! Coxas, peitos, barriga, bunda... Adorava! (Relatos de Memória-Criança).

Pensar, assim, em criança preta-viada, é então pensar em coletivo, em grupalidade. É em coletivo que tais crianças saciam seus desejos, matam suas curiosidades, criam perguntas e são precarizadas. É na não-assimilação com outros modelos de infâncias (brancos, burgueses, neoliberais), que a infância preta-viada surge, tornando-se ameaçadora, perigosa e antifascista.

Então, é também em bando que tais crianças desmancham seus medos que as paralisam, e abandonam caminhos que lhe foram condicionados a serem trilhados. É em manada que a criança-preta-viada entra em becos, matas, trilhas, casas abandonadas ou repletas de familiares, sobe escadas, esconde-se em baixo da mesa ou da cama, para, no fim, experimentar sua viadagem, constituindo para si uma nova possibilidade de negritude. Uma negritude que não obedece às expectativas de um modelo racista de masculinidade.

Eu tenho memórias de sempre ter sido uma criança afeminada, usava camisa na cabeça pra falar que era meu cabelo azul, e gostava de brincar com "coisas de menina", mas vivia muito entre o menino. Como era uma cidade pequena todos costumavam frequentar os mesmos lugares para poder brincar. E foi nesses lugares onde tivemos as primeiras experiências sexuais! Brincadeiras de crianças curiosas, onde os mais velhos sempre se aproveitavam dos mais novos. Era quase sempre a mesma coisa, vamos brincar, e ímos pra casa de café abandonada, onde depois de brincar ficávamos sarrando ou fazendo sexo oral. Quando uma criança via duas entrando no local sempre ficava de olho, a intenção era pegar no flagra e poder chantagear com isso todas as vezes que queria "meter", que era o sarro, né? (Relatos de Memória-Criança).

Nessas experiências grupais, as relações de dependência, hierarquia e domínio se despontencializam. Os mais velhos acham-se no comando, mas apenas como aqueles que negociam o prazer, o uso da carne, da pele. Ao mesmo tempo, entretanto, não é possível dizer que elas se diluem por completo, pois, ao entendermos que as crianças são sujeitos sendo majoritariamente educados por pedagogias fascistas, por mídias adultocêntricas, por psicologias desenvolvimentistas, compreende-se que tais relações de poder podem e estão sendo estabelecidas entre essas crianças. Não existe 
contato ou lugar purificado de práticas de poder. E, honestamente, também não é essa a questão. É questão de grito, de arrombo de lógicas de corpo inexistente que nos interessam.

Questionamo-nos, talvez, como criar um plano de potencialização de desejos, ou, antes, como espalhar viralmente os espaços em que as intensidades da carne não se desviam das crianças, mas começam a partir delas em jogos da carícia e respeito, de afecções e brincadeiras.

Teve uma vez que a gente tava no bequinho do lado do cemitério e foi um alvoroço só quando passaram dois caras bem mais velhos que a gente. E eles resolveram passar bem ali do nosso lado! A gente lá, trocando isqueirinho, e passam dois caras. Todo mundo já foi levantando as calças... mas eles nem ligaram. Lembro até hoje o que eles falaram: "Opa!". Um bando de criança de uns 10-12 anos se masturbando do lado do cemitério e tudo o que eles falam foi "Opa"? Fiquei louca para chamar eles para se juntarem a gente! (Relatos de Memória-Criança).

\section{o verso dos retratos de infâncias}

"O tempo das crianças [...] acontece pela animalidade", marcando, nas suas aparições passageiras, "paixão desordenada, desejo do instante, pele sem vestes, cheiro de terra" (SKLIAR, 2014, p. 141). O tempo das crianças, heterotópico, cria outras possibilidades de infâncias. Infâncias essas que inventam sua autonomia, não como a separação utópica do mundo adulto já estabelecido de alguma maneira entre nós; mas como outros modos de relação com a adultez.

A criança é sempre novidade, por isso ela assusta. Ela evoca a incerteza e materializa as possibilidades que tememos tornarem-se reais. Possibilidades de gênero, sexualidade e raça. Crianças produzem coreografias que desestabilizam modelos identitários impostos a elas. A criança experimenta-se em intensidade, em fluxo, em trânsito; ela nunca está estacionada em um modelo de existência. As crianças experimentam as identidades, mas não se satisfazem com elas. Não se importam. Nesse sentido, é possível pensar que as crianças negras, moradoras de bairros periféricos nos centros urbanos, causam incômodo por onde passam, 
deslocamentos crianceiros, conversas transviadas: coisas da educação e de afirmação de uma vida que importa

configurando sua negritude como contrariedade aos processos de socialização predominantes, estruturados e impostos em processos de colonização. A viadagem configura assim uma raça maldita em ruptura com o ideal de humano (branco, heterossexual, europeu, etc.).

A potência da criança preta viada, é preciso notar, não é garantia de imunidade às angustias, às paixões tristes. Pelo contrário. Essas crianças são potentes justamente por estabelecerem linhas de resistência frente às violências, ao racismo, à heterossexualidade compulsória, à misoginia. A potência das viadas crianças pretas se afirma no contra-ataque aos processos identitários binários e racistas que pretendem enquadrá-las e adestrá-las. Querem-lhes com almas brancas, ainda que de tez escura; querem-lhes cisgêneras, heterocentradas e, ainda assim, as crianças riem, somem, escondem-se atrás de árvores e, por serem tão escuras quanto os troncos, passam despercebidas. Potências do segredo. Essas crianças incomodam, pois apresentam formas ainda não institucionalizadas de experienciar o corpo negro. Elas propõem, como bixas pretas, torções em masculinidades e feminilidades negras; configuram a frente inventiva de um povo potência. A bixa preta feita criança dança no revés da identidade. A criança preta viada não precisa necessariamente se compreender enquanto negra ou viada para desestabilizar gêneros, raças e projetos de masculinidades e feminilidades. Contudo, nós, adultos, insistimos em encaixá-las nos modelos identitários. A bichice, antes que palavra organizadora, é senha de passagem para mil diabrezas.

Para acompanhar os movimentos de fuga dessas pretas viadas crianças, antes é preciso compreender que, ao agruparmos e nomearmos elas, corremos constantemente o risco de capturá-las. Assim como o rapto periga tornar-se fuga destinada ao retorno ou sequestro objetificante da criança, o nome periga tentar definir ou representar, buscando enquadrar a força de nos conduzir aos lugares mais distantes que os signos possuem a uma rota estável, constante, morta. Assim, é 
necessário ainda questionar: como essas crianças de corpo negro afeminado chegam a recair em modelos enrijecidos de masculinidade?

A questão não é apenas se há um sentimento de pertencimento dessas crianças para com as categorias ou grupos sociais já existentes e, sequer, criar uma categoria nova para comprá-las, para arrematá-las noutros discursos. Devemos nos atentar às rachaduras que seus corpos negros-afeminados produzem nas expectativas que se constroem sobre eles. Com Larrosa (2004, p. 184), vamos tentando enxergar as infâncias que abrem um "vazio no qual se abisma o edifício bem construído de nossas instituições de acolhida".

Estudos sobre infâncias exigem coragem e desejo para lidar com o novo, com o diferente, com o absurdo. Sim, crianças fazem, vivem, dizem, gritam absurdos em seus corpos e, bizarramente, nós ignoramos esses absurdos em uma proposta de regularizar tudo, de controlar, de validar. Viramos para as crianças e fazemos a única pergunta latina que não lhes interessa: "Quid juris?”. "Com que fundamento você diz isso, minha cara?". Criando vagabundeios a cada piscadela, ou somos arrematados com seus movimentos - que fazem nascer em nós um vagabundo que, enfim, passa a ter tato para com as infâncias -, ou elas somem. Ainda não somos foragidos, para nosso desgosto; mas, com muito afinco, procuramos essas crianças-infâncias, essas crianças-viadas-pretas, para escaparmos pela sombra, pelas ruelas, pela esquerda.

\section{referências}

BUTLER. Judth. Quadros de Guerra: quando a vida é passível de luto. Trad. Sérgio Lamarão e Arnaldo Marques da Cunha. Rio de Janeiro: Civilização Brasileira, 2015.

DESPENTES, Virginie. Teoria king-kong. Trad. Márcia Bechara. São Paulo: n-1 edições, 2016.

FOUCAULT, Michel. Vigiar e Punir: história da violência nas prisões. Trad. Raquel Ramalhete. 25. ed. Petrópolis: Vozes, 2002.

FOUCAULT, Michel. O corpo utópico; as heteropias. Trad. Salma Tannus Muchail. São Paulo: n1 edições, 2013.

FOUCAULT, Michel. Os anormais: curso no Collège de France (1974-1975). São Paulo: Martins Fontes, 2014.

LARROSA, Jorge. Pedagogia Profana: danças piruetas e mascaradas. Trad. Alfredo Veiga-Neto. Belo Horizonte: Autêntica, 2004. 
deslocamentos crianceiros, conversas transviadas: coisas da educação e de afirmação de uma vida que importa

NAJMANOVICK, Denise. O sujeito encarnado: questões para pesquisa no/do cotidiano. Rio de Janeiro: DP\&A, 2003.

SCHÉRER, René. Não tocar. In: LAPASSADE, G.; SCHÉRER, R. O corpo interdito: ensaios sobre a educação negativa. Lisboa: LTC, 1982. p. 73-129.

SCHÉRER, René. La pedagogía pervertida: sobre las relaciones entre educación y sexualidad. Barcelona: Laertes, 1983.

SCHÉRER, René. Pré-âmbulo: o fracasso de uma apropriação. In: FOURIER, C. A infância emancipada: textos sobre educação. Lisboa: Antígona, 2007. p. 7-38.

SCHÉRER, René; HOCQUENGHEM, Guy. Coir, álbum sistemático da infância. Trad. Eder Amaral e Silva. Rio de Janeiro: UERJ, 2016.

SKLIAR, Carlos. Pedagogia (improvável) da diferença: e se o outro não estivesse aí? Trad. Giane Lessa. Rio de Janeiro: DP\&A, 2003.

SKLIAR, Carlos. O ensinar enquanto travessia: linguagens, leituras, escritas e alteridades para uma poética da educação. Trad. Adail Sobral [et al.]. Salvador: EDUFBA, 2014.

recebido em: 13.04 .2018

aprovado em: 29.04 .2018 